\title{
VERBAL INTERACTION IN ENGLISH CLASSROOM USING FLANDERS INTERACTION ANALYSIS CATEGORIES SYSTEM (FIACS)
}

\author{
*Fitri mardiyana \\ **Prof.Dr.Zainuddin,DIP.TEFL.,M.Hum. \\ **Johannnes Jefria Gultom, S.Pd., M.Hum.
}

\begin{abstract}
Mardiyana, Fitri.Registration Number: 2132121015. Verbal Interaction in English Classroom Using Flanders Interaction Analysis Categories System (FIACS) .A Thesis. English Educational Program,English and Literature Department, Faculty of languages and Arts,Medan State University, 2018.
\end{abstract}

The thesis deals with the dominant category used by teacher and the students during English classroom interaction, and the percentage of teacher's talk and students' talk during English classroom interaction using Flanders Interaction Analysis Categories System (FIACS). Moreover, this study used descriptive qualitative design .The data of this study were utterances between English teacher and students during English classroom in XI-2 IPA of SMA Negeri 11 Medan.The instruments for data collection were observation tally sheet and video recording. The result showed all of the categories used in the teaching and learning process. It found from the percentage of all categories, the dominant category used by the teacher was Giving Direction $(40.41 \%)$ ). In the other hand the dominant category used by students was Student Talk-Response (57.60\%). In addition, the percentage of Teacher Talk was 59.76\%, and the percentage of Student Talk was $36.72 \%$ during classroom interaction in English lessons .It showed, the teacher more active and dominant talking than the students during verbal classroom interaction.

Key words: Verbal Classroom Interaction, Teacher Talk, Student Talk, Flanders Interaction Analysis Categories System 
*Graduate Status

**Lecturer Status

\section{INTRODUCTION}

\section{Background of Study}

Classroom interaction is the action that performed by the teacher and the students in the process of teaching and learning in the classroom. In classroom interaction has verbal interaction and non verbal interaction. When, students do their written and oral interaction in the classroom, it means that they have done their verbal interaction and for their non verbal interaction showed from their responses such as head-nodding, hand raising and so on without using their words in their interaction in the classroom (Meng 2011:98).

Classroom verbal interaction aims at meaningful communication among the students in their target language. However, that is to make the students improve their ability in learning English and use English in their life communication at least in the classroom during the English class.

Additionally, teaching and learning process in the classroom, interaction between teacher and students are very important. Interaction between teacher and students establish the success of teaching-learning process. In the English Foreign Language (EFL) classroom, the role of teachers is very important to interact with the students in giving the direction and explanation, and checking the students' comprehension about the target language (Yanfen \& Yuqin 2010:76).

Nunan (1998) says that many language teachers were surprised of the amount of talk they use in the classroom. It is for about 70 to 80 percent out of class time was spent mostly by teacher talk. It means, the teacher too active in the classroom, should the student who active more than teacher.

Flanders Interaction Analysis Categories System (FIACS) Technique is an observational tool used to classify the verbal behavior of teachers and students as they interact in the classroom. Flanders' instrument was designed for observing only the verbal communication in the classroom and nonverbal gestures are not taken into account. Flanders Interaction Analysis Categories (FIAC) is a Ten 
Category System of communication possibilities. There are seven categories used when the teacher is talking (Teacher Talk) and two when the students is talking (students Talk) and tenth category is that of silence or confusion.

So, based on the researcher's observation in SMA Negeri 11 Medan, it was found that the common interaction occurred in the classroom that the students would participate to talk if the teacher initiated, encouraged, and asked the students to talk. In fact, the categories of teacher talk had great influence to make the students to talk in the classroom. That was the basic reason why the researcher wanted to found out the dominant category used by teacher and students during classroom verbal interaction in English lesson. Then, to know how much the teacher and students spent time to talk during teaching and learning process in English lesson.

From the previous study about Classroom verbal interaction "The Analysis of Teacher Talk and Learner Talk" by Nurhasanah (2013). The main objectives of his research were to find out the types of teacher talk and student talk in classroom at tenth grade of senior high school in Bandung. This study proves the findings from the previous research that the teacher plays dominant part in classroom interaction suggested by Nunan (2001). The Percentage of teacher talk was $54 \%$ and students was $44 \%$, and silence was $2 \%$. However, the dominance of the teacher talk is valuable since the teacher fully uses target language as language input and it is proposed to direct the students to express their ideas. The study comes up with some categories of teacher talk, beginning from the highest percentage to the lowest one : asking question, giving direction, criticizing, accepting ideas, lecturing, accepting feeling and praising. Regarding to students talk, this study has shown two types of the students talk covering response and initiation .Those categories confirm Flanders' Interaction Analysis Categories System (FIACS) developed by Flanders (1970).

Based on the explanation above, the researcher wanted to conduct a research entitled "Classroom Verbal Interaction in English Classroom Using Flanders Interaction Analysis Categories System (FIACS) ". 


\section{REVIEW OF LITERATURE}

Interaction is the way to get information. Verbal interaction especially, is the most important thing for the second language learners to get and learn language in order to communicate in the target language. Classroom is the place for the second language learners to enrich and absorb their knowledge about the target language, so the classroom verbal interaction becomes one of the important things in learning a new language as well as the first language.

Brown (2001:165) defines interaction as the collaborative exchange of thoughts, feelings, or ideas between two or more people, resulting in a reciprocal effect on each other. Successful verbal interactions will occur when both the teacher and students could completely understand what each other means. It happens verbally among the teacher and students during the teaching learning activity.

Flanders Interaction Analysis is a system of classroom interaction analysis which is concerned with verbal behavior only, primarily because it can be observed with higher reliability than can non-verbal behavior and more also, the assumption made that the verbal behavior of an individual is an adequate sample of his total behavior. Flanders Interaction Analysis Categories(FIAC) is a Ten Category System of communication possibilities. There are seven categories used when the teacher is talking (Teacher Talk) and two when the students is talking (students Talk) and tenth category is that of silence or confusion.

\section{RESEARCH METHODOLOGY}

This research was conducted by using descriptive qualitative research which is adapted from Creswell (2009:4) that descriptive qualitative research is exploring and understanding the meaning individual or groups ascribe to social or human problem.So, in this research was consist of eight phases: (1) Deciding the code of teacher talk and student talk 
, (2)Transcribing the verbal classroom interaction, (3) Classifying the Data, (4)

Giving a code number, (5) Plotting the code number into a matrix ,(6) Calculated the percentage of the ten categories by Flanders' formula,(7)Calculated the amount of teacher talk and student talk by Flanders' formula,(8) The finding were taken into conclusion and suggestion which refer to the objectives of the research

\section{The Subject of the Research}

The subjects of this research were The English teacher and students in IX1class of SMA Negeri 11 Medan, academic years 2017/2018.

\section{The Instruments of Data Collection}

The data of the research were collected through observation tally sheet, and video recording during English Classroom.

The Techniques of Analyzing the Data

The data of this research were target need and need analysis. The data were analyzed to get the information of verbal interaction between the students and teacher in English classroom based on Flanders Interaction Analysis Categories System.

\section{RESEARCH FINDING}

A. The dominant category which used by teacher and the students during verbal classroom interaction in English

Based on the analyzed observation and tally sheet, the researcher was found that for the teacher, the dominant category which used in first meeting and second meeting was Giving direction with $20.14 \%$ in the first meeting and $20.27 \%$ in the second meeting. Then the total percentage of Giving direction was $40.41 \%$. In the other hand, the dominant category that used by the students in the first meeting was Student Talk-Response with $26.14 \%$ in the first meeting and $31.45 \%$ in the second meeting. Then the total percentage of Students Talk-Response was $57.59 \%$. 
B. The percentage of Teacher Talk and Students talk

In this study the researcher found out during learning teaching process in English lesson, the teacher more than talking than students. The percentage of Teacher Talk in the first meeting was $61.48 \%$ and for the second meeting was $58.04 \%$. The average percentage of Teacher Talk during English Lesson was $59.76 \%$. On the other hand, the percentage of Student Talk in the first meeting was $35.68 \%$ and in the second meeting was $37.76 \%$. The average percentage of Student Talk was $36.72 \%$.

\section{CONCLUSIONS AND SUGGESTIONS}

Conclusions

1. The teacher and the students used all the categories of the verbal classroom interaction purposed by Flanders during the English lessons at eleven grade of SMA Negeri 11 Medan. The teacher applied Accept felling (1.75\%), Praises or Encouragement (11.95\%), Accepts or Uses Ideas of Students (9.13\%), Asking Question (29.53\%), Lecturing (20.41\%), Giving Direction (40.41\%), and Criticizing or Justifying Authority (15.84\%). The dominant category applied by the teacher was Giving direction (40.41\%). On the other hand, the students applied Student Talk-Response (57.60\%), and Student Talk Initiation (13.73\%). The dominant category applied by the students was Students Talk-Response (57.60\%).

2. The percentage of teacher talk in verbal classroom interaction during the English lessons at eleven grade of SMA Negeri 11 was $59.76 \%$.In addition, the percentage of Student Talk was $36.72 \%$. It means that the teacher more active than the students during classroom verbal interaction in English lesson.

\section{Suggestion}

1. The English teacher and the students to can improve their interaction during verbal classroom interaction, and give more to practice their language. 
2. The students to be active in the classroom. In addition, this study expected could help and give the more information about classroom interaction, especially for further study.

\section{REFERENCES}

Brown, H. D. (2007). Principles of Language Learning and Teaching USA: Pearson Education.

Christine H. \&Manzoorul. A. (2013). Classroom dialogue: a systematic review across four decades of research. Journal Cambridge Journalof Education. Vol.43, No.43.

Creswell. (2009). Educational Research: Planning, Conducting, Evaluating Quantitative and Qualitative Research (3rd edition). New Jersey: Pearson Education International.

Dagarin,M.A.(2004). Classroom Interaction and Communication Strategies in Learning English as a Foreign .Sloven :Sloven University.

Evans, R., Kilfoil, W., \& van der Walt, C. (2012). Learn 2 teach: English language teaching in a multilingual context. (4th Ed.). Pretoria: Van Schaik.

Flanders, N. (1970). Analyzing Teacher Behavior. New York: Addison-Wesley.

Fraenkel, J. R., \&Wallen, N. E. (2009). How to design and evaluate research in education, seventh edition. New York: McGrawHill Higher Education.

Goronga.(2013). The Nature and Quality of Classroom Verbal Interaction: Implication for Primary School Teachers in Zimbabwe . Journal Social Sciences and Humanities Vol.4 No.2

Hatch,E.(1992).Discourse and Language Education. Cambridge: Cambridge University.

Inamullah, M. (2005). Pattern of Classroom Interaction at Different Educational Levels in the Light of Flanders Interaction Analysis. Pakistan.

Inamullah, M. (2008). Teacher-Student Verbal Interaction Patterns At The Tertiary Level Of Education. Journal Contemporary Issues in Education Research (CIER)Vol.1 No.1 
Khadidja, K. (2010). The effect of classroom interaction on the developing the learners' speaking skill. Thesis submitted in partial fulfilment of the requirement for Master Degree in Language Sciences (TEFL). University of Constantine.

Larsari, V.N. (2011). Learners' communicative competence in English as a foreign language (EFL). Iran: Islamic Azad University

Luu,T\& Nguyen, T. (2010). Theoretical Review on Oral Interaction in EFL Classrooms. Journal Studies in Literature and LAauage. Vol.1. No.4

Malamah-Thomas, A. (1987). Classroom Interaction. Oxford: Oxford University Press.

Mingzhi. (2005). Enhancing interaction in our EFL classroom.CELEA Journal Vol. 28. No. 2

Nisa, S.H. (2014). Classroom Interaction Analysis in Indonesia EFL Speaking Class. Journal of English Education Vol.2 No.2

Nyambura, N. J. (2012). Verbal classroom interaction patterns of selected secondary home science teachers with their students in Nairobi Province. Thesis, Kenyatta University.

Pasassung. N. (1995). The Teaching of EFL in the Context of Indonesia's Remote Areas: A Case of Southeast Sulawesi, A Paper Presented at 2nd Regional TEFLIN Conference, UNS Solo.

Rivers, W. M. (1987). Interactive Language Teaching. Interaction as the Key to Teaching Language for Communication. New York: Cambridge University Press.

Silverman, D. (2011). Interpreting qualitative data: A guide to the principles of qualitative research. London: SAGE.

Simich\&Dudgeon. (1998). Classroom Strategies for encouraging Collaborative Discussion. Journal Directions in Language and Education. Vol.12

Suryati, Nunung. (2015). Classroom Interaction Strategies Employed by English Teachers at lower secondary schools.Indonesia: TEFLIN Journal Vol.26 No.2 
Tatar, S. (2005). Why Keep Silent? The Classroom Participation Experiences among Non-Native English Speaking Students.Journal Language and Intercultural Communication. Vol. 5, No. 3 \& 4. pp. 284-293

Tuan, L.T., \&Nhu, N.T.K. (2010). Theoretical review on oral communication in EFL classrooms. Studies in Literature and Language Journal Vol. 1., No. 4, 2010, pp. 29-48.

Ur, P. (2000). A Course in Language Teaching: Practice and Theory. Foreign Language Teaching and Research Press.

Yanfen, L. \& Zhao Yuqin. (2010). A Study of Teacher Talk in Interactions in English Classes. Harbin Institute of Technology: Chinese Journal of Applied Linguistics (Bimonthly) Vol.33 No. 2. 